\title{
Comprehensive Evaluation of Environmental Dimension Reduction of Multi-Type Islands: A Sustainable Development Perspective
}

Shaoyang Chen ( $\nabla$ nmdiscsy@126.com )

Tianjin University

$\mathrm{Na}$ Liu

Tianjin University

Li Xiao

Tianjin University

Yanwei Gong

Tianjin University

Yun Xiao

Chinese Academy of Surveying and Mapping

\section{Research Article}

Keywords: Island environment, Sustainability, Indicator construction, Evaluation model, Factor analysis, Development path

Posted Date: July 12th, 2021

DOI: https://doi.org/10.21203/rs.3.rs-636482/v1

License: (1) This work is licensed under a Creative Commons Attribution 4.0 International License. Read Full License

Version of Record: A version of this preprint was published at Environmental Science and Pollution Research on November 8th, 2021. See the published version at https://doi.org/10.1007/s11356-02117240-9. 


\section{Comprehensive evaluation of environmental dimension reduction of multi-type islands: a sustainable development perspective}

1 Shaoyang Chen ${ }^{1, *}$, Na Liu ${ }^{1}$, Li Xiao ${ }^{1}$, Yanwei Gong ${ }^{1}$, Yun Xiao ${ }^{2}$

$2 \quad{ }^{1}$ School of Marine Science and Technology, Tianjin University, Tianjin 300072, China

$3{ }^{2}$ Xian Research Institute of Surveying and Mapping, Xian 710061, China

4 ABSTRACT

In recent years, the exploration and sustainable development of islands is getting more and more attention around the world. However, the development of China's islands is somewhat disorder and spatial unbalanced. Therefore, we need to conduct a scientific assessment of the islands in order to fully understand the islands. In this paper, We analyze the possible development path of the islands by evaluating the value of the islands. To be specific, we present an extensive evaluate model design based on analysis of the environmental resources conditions, economic values, and existing problems of the seven typical islands in China. This model is applied to evaluate the sustainability levels and development advantages of seven typical islands. The island's evaluation results are consistent with the island's actual development level, which proves that the model is believable. Generally, the more indicators involved in the evaluation model, the more accurate the evaluation result will be. However, numerous indicators will cause two problems. One is that some indicators are highly correlated and make the evaluation results inaccurate. Therefore, it is necessary to remove redundant indicators; the other is that the calculation process will be cumbersome. In this study, we used factor analysis to solve the problems, making the evaluation results more accurate. Meantime, the experiment has proved that the model can simultaneously use multiple types of islands as samples for unified evaluation.

20 Keywords: Island environment, Sustainability, Indicator construction, Evaluation model, Factor 21 analysis, Development path

\section{INTRODUCTION}

23 Since the 20th century, oceans and islands have gradually become the focus of national and social 24 attention(Zhang et al., 2020; He and Wang, 2020; Zheng et al., 2020). The importance of island 25 development, management, ecological protection, etc. is increasing day by day(Liu et al., 2018), and the island view of coordinated development, green development and sustainable development has gradually formed. In response to the island's complex geography, resource endowments, and various conflicts arising from the development process(Douglas, 2006), the island's development situation tends to shrink. Affected by the long-term concept of valuing land and ignoring sea, as well as unfavorable factors such as being far away from the mainland, inconvenient transportation, and hard life, the development of China's islands is basically in a lagging, disorderly, and extensive stage. In the process of island development, there are the following problems: the development order is chaotic, the construction level lags behind, the development level is low, and the resources and environment are seriously damaged. In recent years, islands gradually towards the ecological island reef construction direction, but still difficult. The island development and construction has stalled, the core reason is the lack of accurate positioning of the island and scientific planning assessment.

\footnotetext{
* Corresponding author: Shaoyang Chen

E-mail address: nmdiscsy@126.com
} 
Western maritime powers and international small island countries have in fact done a lot of scientific research on the scientific development and utilization of islands(Rigg and Richardson, 1934; Tokusige, 1939), such as island management(Kim, 2020), island ecology(Petridis et al., 2017) and non-resident island development and utilization(Hwang and Ko, 2018). Many countries with islands in the world are more likely to adopt centralized and specialized agency management systems for island management. Centralized formulation of marine island master plans through a unified organization makes it easier to achieve high resource utilization and ecological environment protection(Shi et al., 2015). International research on islands mostly focuses on ecological and environmental protection. The restoration of island ecological environment is exemplified by New Zealand. As a small island country, New Zealand attaches great importance to the research of ecological restoration, and has made a series of achievements in island ecological restoration(Towns and Ballantine, 1993). Although China's effort on island ecological environment protection started relatively late compared to foreign countries, with China's emphasis on islands in recent years, the protection and management works of islands has been increasing. Some achievements have been made in island development(Shen, 1995), island protection(Zhang et al., 2020) and ecosystem evaluation(Chen and Dong, 2019). Compared with other countries with more successful island development (e.g. Australia, Thailand, etc.), the overall development and utilization level of uninhabited islands in China is low, and both efficiency and benefit are not commensurate with the relatively superior natural endowment status.

The concept of sustainable development can be traced back to the 1970s, and then quickly penetrated into all areas of social development. In 2004, some experts and scholars(Li and Wang, 2004) made the following definitions for the sustainable development of the island: adapt measures to island conditions, plan rationally, rely on scientific and technological progress, strengthen legal management, and rationally and effectively develop and utilize the island's ecological environment without reducing its carrying capacity so that it not only meets the needs of the present generation and does not pose a hazard to the needs of future generations. Since then, the sustainable development of the island has become the main line in the study of the island environment. The development of islands is susceptible to human activities and environmental changes(Brauko et al., 2020). From the perspective of politics(Liao and Liu, 2019), economy(Baldacchino, 2006; Liu et al., 2020; He et al., 2020), resources(Zheng et al., 2020; del et al., 2020), and the environment(Liu et al., 2017), disorderly islands' human activities and economic development models are not conducive to the sustainable development of islands(Zhao et al., 2016). The vulnerability of islands compared to land emphasizes the importance of island management and planning. Establish the concept of sustainable development with strategic significance and a fair and just support system to provide a solid foundation and guarantee for the sustainable development of the island(Wang et al., 2006). Domestic and international research on the application of the concept of island sustainable development involves ecology(Li et al., 2019), tourism(Moreno, 2005), fishery(Karcher et al., 2020), land resources(Zhang and Xiao, 2020), etc. Its emphasis is on balancing the natural ecology and social development of the island. For small island States in particular, sustainable development research is more relevant. Small island States pay more attention to how to achieve the sustainable development of islands(Tilley et al., 2019), and the study of protecting the island's ecological environment(Hafezi et al., 2020) and socio-economic development(Mauthoor, 2017) is more in-depth. scholars at home and abroad have conducted research on the evaluation system of island sustainable development(Ke et al., 2013; Long et al., 2020; Nesticò and Maselli, 2020). Since the establishment of the evaluation index system for the sustainable development of islands in 2004, many scholars have successively evaluated the sustainable development of islands(Xu et al., 2020). So far, representative evaluation models for the sustainable development include analytic hierarchy process(Zhu and Wang, 2017), ecological footprint model(Fang et al., 2018), variable fuzzy set theory comprehensive evaluation model(Ke et al., 2014), and catastrophe progression method( Gao et al., 2019). The existing island evaluation methods are not perfect. When there are too many indicators, the calculation process is cumbersome. On the other hand, it is difficult to accurately reflect the environmental conditions of the island with fewer evaluation indicators. Therefore, the evaluation results have limitations. Although China has made some achievements in the evaluation of the sustainable development of islands, there are still many problems in the investigation and evaluation of the current situation of the island environment. The 90 lack of understanding of the islands is not conducive to the sustainable development of the islands. The 
91 assessment of foreign islands is mainly centered on risk assessment, which explores the impact of

92 disturbance on the island environment itself and human society, involving anthropogenic factors such as

93 fisheries fishing(Gilman et al., 2014) and natural factors such as hurricane crossing(Sealey et al., 2020).

94 With the development of the island evaluation system, the evaluation system is becoming more and more 95 in-depth, comprehensive and three-dimensional. At present, there is no unified and universally applicable island evaluation model at domestic and abroad(You et al., 2015). There is basically no integrated framework, including various methods. This situation obscures the overall assessment(Karampela et al., 2017). Experts and scholars mainly evaluate the environment of a single island to discuss the development level of this island and give development suggestions. Drawing on the island research experience of major international marine countries and small coastal island countries, combined with the results of the evaluation of the sustainable development of domestic islands, this study uses network information collection method and statistical analysis method to study and analyze the representative data of the sustainable development of the islands, and constructs the classification and evaluation system of factor analysis method. The study uniformly evaluated seven different types of islands to test the feasibility of the evaluation method. Using seven different types of islands as samples for unified evaluation, not only reduces the amount of calculation for individual evaluation of each island, but also helps analyze the development of different types of islands. This is conducive to the state's hierarchical and classified management of islands and the macro-control of the development of different types of islands. The evaluation provides a theoretical basis for the sustainable development of the islands and a decision-making basis for the formulation of island development measures.

\section{MATERIAL AND METHOD}

\section{$112 \quad 2.1 \quad$ The study area}

113 The results of the national survey of island names in sea areas show that there are more than 11,000 islands 114 in China(Pan et al., 2018), including 12 major island counties (cities and districts)(Zhao and Zheng, 2017).

115 The total area of islands accounts for about $0.8 \%$ of China's land area. According to whether the island has 116 a household registration, it is divided into resident islands and non-resident islands. The evaluation model 117 requires that the evaluation objects have universal applicability, so the study selected seven representative 118 islands in terms of residents' life, tourism, natural environment and ecology.

119 Table 1 Evaluation target situation

\begin{tabular}{|c|c|c|}
\hline Island type & Island name & Reason for selection \\
\hline \multirow[b]{2}{*}{ Social life } & Chongming Island(D1) & \multirow{2}{*}{$\begin{array}{l}\text { It has a vast area, a large population, complete functions, } \\
\text { industries, and infrastructure, and a high level of political, } \\
\text { cultural, transportation and economic construction. }\end{array}$} \\
\hline & Zhoushan Islands(D2) & \\
\hline $\begin{array}{l}\text { Leisure } \\
\text { travel }\end{array}$ & $\begin{array}{l}\text { Weizhou Island(D3) } \\
\text { Miaodao Islands(D4) } \\
\text { Nanji Island(D5) }\end{array}$ & $\begin{array}{l}\text { The area is relatively small, the permanent population is small, } \\
\text { and the island has a unique landscape. The island's economic } \\
\text { development is dominated by tourism. }\end{array}$ \\
\hline \multirow{2}{*}{ Ecology } & Shedao Island(D6) & $\begin{array}{c}\text { The only island in the world where only vipers live. There is a } \\
\text { national protection zone for vipers on the island to protect snake } \\
\text { resources. }\end{array}$ \\
\hline & Shanhu Island(D7) & $\begin{array}{l}\text { It is an island composed of coral reefs. The island is rich in coral } \\
\text { and guano resources. It is one of the islands with the richest } \\
\text { phosphate rock. }\end{array}$ \\
\hline
\end{tabular}




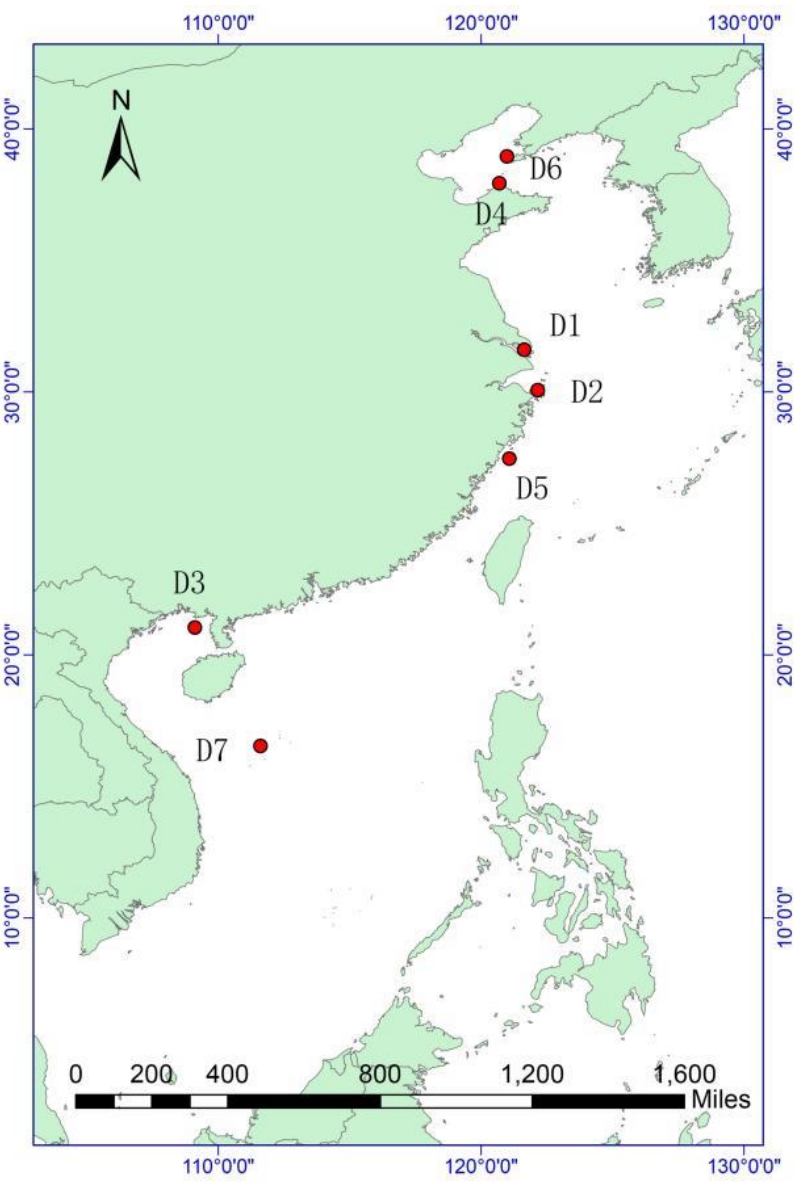

Fig. 1 Location of evaluation object

\subsection{Data acquisition}

123 The island is a special regional type with a series of unique natural and economic characteristics. As a complete geographical unit, the island's environmental elements are special. Therefore, it is necessary to combine the personality of the island to explore its development model. The scientific development of islands should follow the natural laws of the islands and adapt to local conditions. The environmental quality of the islands should be assessed on the basis of accurate acquisition of the island's ecological environmental quality information, so as to formulate a reasonable development plan for the sustainable development of the islands. Large-scale islands that are well developed and utilized, such as Chongming Island, Zhoushan Island, Weizhou Island, and Nanji Island, can separately assess resources, environment and society according to island types and development and utilization conditions; Unmanned islands with special functions such as Shanhu Island and Shedao Island should be evaluated according to the characteristics of the island.

134 The island survey is the basis for the ecological environment quality assessment of the island. Data acquisition methods include statistical yearbooks, data and literature inquiries, field surveys and measurements, satellite remote sensing and camera equipment monitoring, etc. The data in this experiment come from various regional government portals and district and county statistical yearbooks, which are authoritative and representative. The study counts the data of China's seven islands in 2019.

139 Table 2 Survey data sources of typical islands 


\begin{tabular}{cc}
\hline Island & Data source URL \\
\hline D1 & http://www.shcm.gov.cn/cmmh_web/html/shcm/portal/index/index.htm \\
& http://www.shanghai.gov.cn/ \\
D2 & http://www.zhoushan.gov.cn/ \\
D3 & http://www.bhhc.gov.cn/ \\
D4 & http://www.weizhouisland.com.cn/ \\
D5 & http://www.changdao.gov.cn/ \\
D6 & http://www.zjpy.gov.cn/ \\
D7 & http://www.dllsk.gov.cn/index_new.asp \\
\hline
\end{tabular}

140 For qualitative data, comprehensively consider the overall impact of the indicators on the islands and the 141 comparative differences between the islands, and quantify the qualitative indicators according to the 0-9 142 scoring method.

\section{$143 \quad 2.3 \quad$ Method}

144 The evaluation system is divided into the following four steps, namely, the construction of the index system, 145 the standardization of data, the determination of weight, and the comprehensive processing of index factors.

146 For the four steps, we filter out the minority and complex evaluation methods, and select the appropriate 147 evaluation methods. These methods are universal and meet the needs of the vast majority of island 148 evaluations.

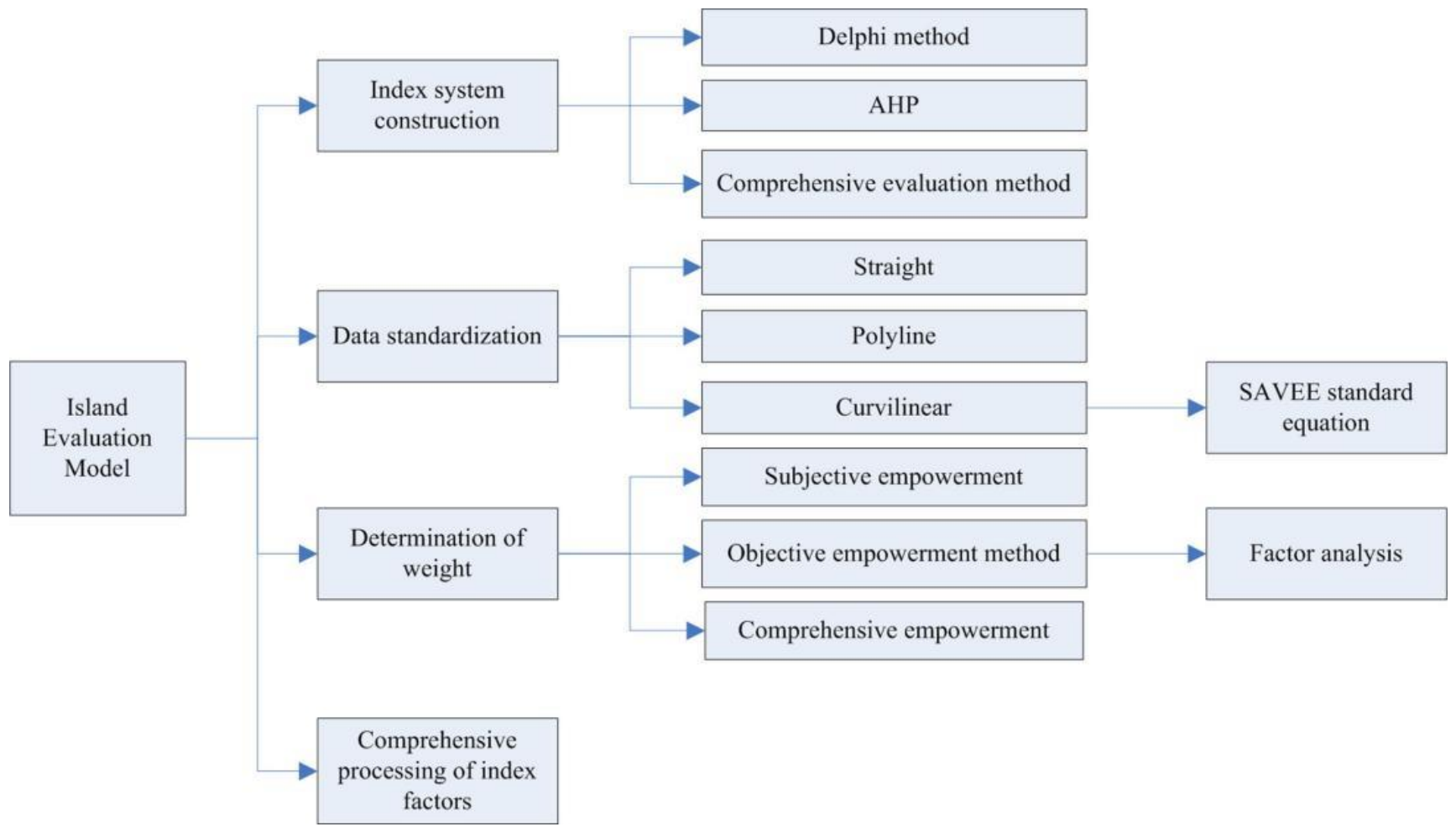

150 Fig. 2 Evaluation method diagram 


\subsubsection{Construction of indicator system}

152 The construction of the qualitative indicators of the island environmental indicator system adopts the

153 Delphi method. Delphi is a process of repeated expert consultation with the aim of integrating all

154 participating expert opinions and ultimately reaching consensus(Yang et al., 2019).

Islands of different types and geographic locations will lead to differences in evaluation objectives. In the actual evaluation process, we select indicators based on the functions of different islands. For the indicator division of uninhabited islands, social factors are negligible, focusing on their natural ecological environment; For tourist islands, appropriately increase the factors of island tourism; For islands with special resources, emphasis is placed on the evaluation of their resource protection.

The research refers to the indicator setting of many experts and scholars in the evaluation of the sustainable development of the island. In the evaluation of the sustainable development of the island, relevant experts and scholars generally set social, resource, environmental, and economic indicators. Some experts and scholars set indicators such as marine industry, development potential, and humanities. In this study, referring to the indicator settings of experts and scholars, and combining the objectives and research objects of this study, two first-level indicators were established, namely nature and society. Then the study select the available secondary indicators. The secondary indicator layer is divided into 38 more detailed indicators, involving the key elements of the island such as culture, economy, resources, ecology, and environment. The island environmental indicator system is constructed.

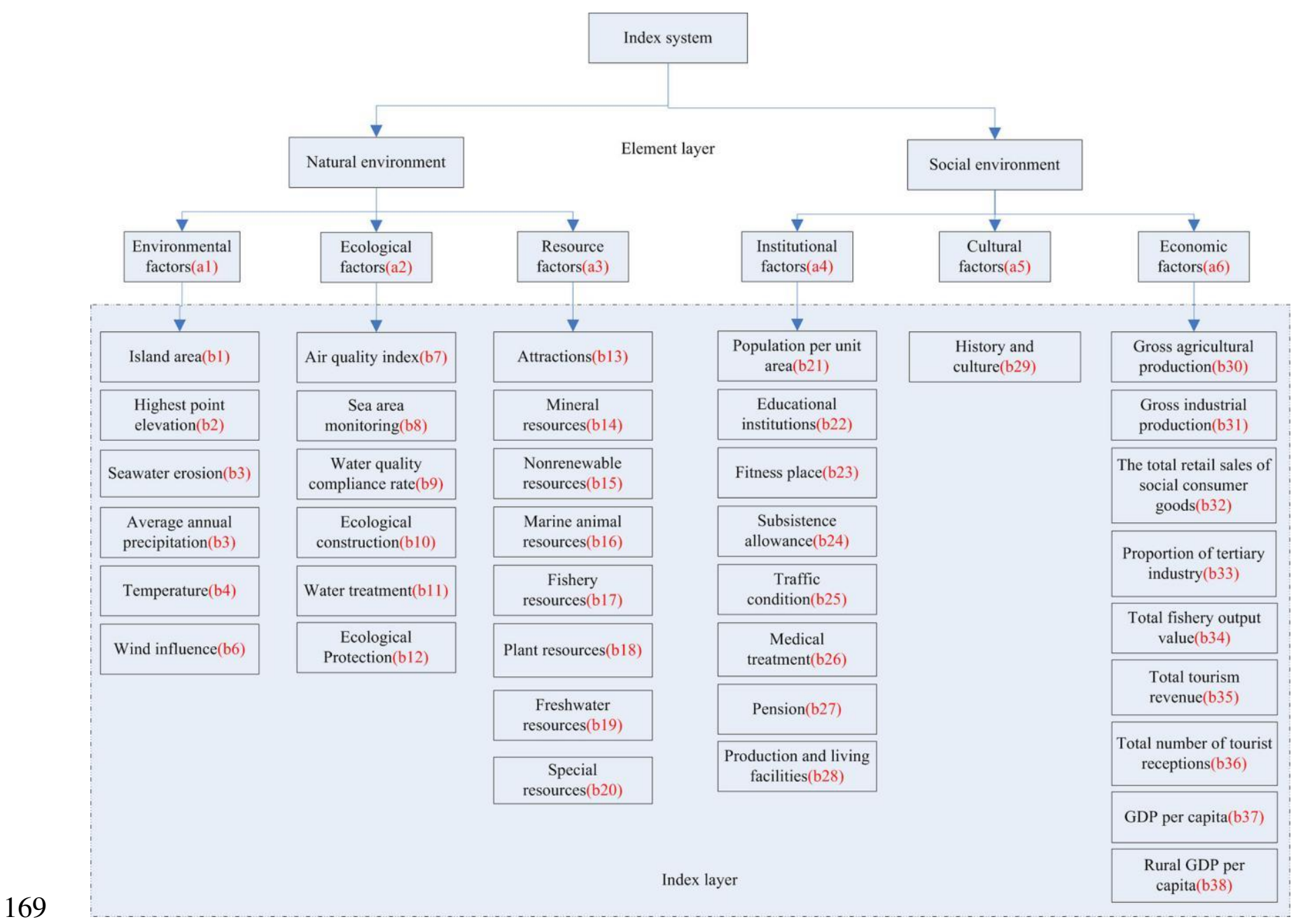

$170 \quad$ Fig. 3 Evaluation indicators and elements of islands 
172 The different formats of the data in the evaluation system result in the incomparability of different 173 indicators, so the selected indicator data should be normalized. The SAVEE method(Chen, 2011) provides

174 a standardized equation to realize the normalization of index data. This study improved the SAVEE

175 standardized equation to achieve the normalization of quantitative data. For quantitative data, within the

176 limit distance $\mathrm{X}$, the research object value $\mathrm{b}$ can be standardized according to the following equation:

177 Table 3 Quantitative data standardization equation

\begin{tabular}{|c|c|c|}
\hline Standardized equation & Quantitative index(b) (X) & $\mathrm{X}$ Definition basis \\
\hline$y=1-e^{9 \times(-1 \times(b+1) \div X)}$ & Island area $\left(150000 \mathrm{hm}^{2}\right)$ & $\begin{array}{c}\text { The area of the island is } \\
\text { positively correlated with } \\
\text { the amount of value, } X> \\
\text { any } x\end{array}$ \\
\hline$y=1-e^{5 \times(-1 \times(b+1) \div X)}$ & Highest point elevation $(30 \mathrm{~m})$ & $\begin{array}{l}\text { The elevation of the island } \\
\text { is too low, it is easy to be } \\
\text { affected by sea erosion, and } \\
\text { the elevation of the highest } \\
\text { point is higher than } 30 \mathrm{~m} \text {, } \\
\text { and the influence of sea } \\
\text { water is less. }\end{array}$ \\
\hline$y=e^{-1 \times(b+1) \div X}$ & Air quality index (AQI) $\left(100 \mu \mathrm{g} / \mathrm{m}^{3}\right)$ & $\begin{array}{l}\text { There is a negative } \\
\text { correlation between AQI } \\
\text { and island value. }\end{array}$ \\
\hline$y=1-e^{5 \times(-1 \times(b+1) \div X)}$ & $\begin{array}{l}\text { Educational institutions }(300) \text {, total } \\
\text { tourism income (500 } 000 \text { yuan), total } \\
\text { reception ( } 800000 \text { people), per } \\
\text { capita GDP (100 } 000 \text { yuan), rural } \\
\text { per capita GDP (100 } 000 \text { yuan) }\end{array}$ & $\begin{array}{l}\text { The index is positively } \\
\text { correlated with the island } \\
\text { value, and the extreme } \\
\text { value is selected according } \\
\text { to the actual situation and } \\
\text { expert experience. }\end{array}$ \\
\hline$y=1-e^{3 \times(-1 \times(b+1) \div X)}$ & $\begin{array}{c}\text { Fitness venues (50), minimum living } \\
\text { allowance ( } 1500 \text { yuan), total } \\
\text { agricultural output value (10 } 000 \\
000 \text { yuan), total industrial output } \\
\text { value (10 } 000000 \text { yuan), total retail } \\
\text { sales of consumer goods (10 000 } 000 \\
\text { yuan), total fishery output value (1 } \\
500000 \text { yuan) }\end{array}$ & $\begin{array}{l}\text { The index is positively } \\
\text { correlated with the island } \\
\text { value, and the extreme } \\
\text { value is selected according } \\
\text { to the actual situation and } \\
\text { expert experience. }\end{array}$ \\
\hline$y=e^{-\frac{1}{2} \times\left(\frac{b-\mu}{\delta}\right)^{2}}$ & $\begin{array}{l}\text { Average annual precipitation (1 } 200 \\
\mathrm{~mm}) \text {, temperature }\left(16^{\circ} \mathrm{C}\right), \text { population } \\
\text { per unit area }\left(4 \text { people } / \mathrm{hm}^{2}\right)\end{array}$ & $\begin{array}{l}\text { The index and the quantity } \\
\text { of value have a normal } \\
\text { distribution, } \mu \text { is the mean, } \\
\text { and } \sigma \text { is the standard } \\
\text { deviation according to the } \\
\text { actual situation. }\end{array}$ \\
\hline
\end{tabular}

According to the impact of a single indicator on the total value of the island's environment, the index is 179 divided into positive correlation index, negative correlation index and normal distribution index. The 180 formula is selected as follows:

181 Positive correlation index:

182

$y=1-e^{k \times(-1 \times(b+1) \div X)}$ 
In the formula: $\mathrm{y}$ is the standardized value, $\mathrm{b}$ is the unstandardized index value, $\mathrm{X}$ is the limit distance value, $\mathrm{k}=\{1,3,5,7,9\}$ ( $\mathrm{k}$ takes the value according to the degree of discretization of the index data, the greater the degree of discretization, the greater the value of $\mathrm{k}$.)

Negative correlation index:

$y=e^{-1 \times(b+1) \div X}$

188 In the formula: $\mathrm{y}$ is the standardized value, $\mathrm{b}$ is the unstandardized index value, and $\mathrm{X}$ is the limit distance 189 value.

190 Normal distribution index:

$y=e^{-\frac{1}{2} \times\left(\frac{b-\mu}{\delta}\right)^{2}}$

192 In the formula: $y$ is the standardized value, $b$ is the unstandardized index value, $\mu$ is the mean, $\sigma$ is the 193 standard deviation.

194 Due to the different types of islands, the difference in index data can be large or small. The study uses qualitative adjustment of the $\mathrm{k}$ value in the standardization formula to standardize different types of island index data to the same dimension, so as to achieve the same evaluation standard.

197 Then standardize the qualitative and quantitative data and transform the standardized index value into a percentile form. The 38 secondary indicators are divided into 20 qualitative indicators and 18 quantitative indicators. The quantitative indicators include 13 positive correlation indexes, 1 negative correlation indexes, and 3 normal distribution indexs. Quantitative data is standardized by SAVEE standard equation, and qualitative data is directly converted into a percentile form. Standardized results are shown as follows:

Table 4 Standardized values of island indexes, where: qualitative index (pink), quantitative index (green), positive correlation index (blue), negative correlation index (yellow), positive and Normal distribution index (red)

\begin{tabular}{cccccccc}
\hline $\begin{array}{c}\text { Index } \\
\text { Island }\end{array}$ & D1 & D2 & D3 & D4 & D5 & D6 & D7 \\
\hline b1 & 100 & 100 & 14 & 28 & 5 & 1 & 1 \\
b2 & 60 & 100 & 100 & 100 & 100 & 100 & 81 \\
b3 & 90 & 30 & 30 & 30 & 30 & 30 & 50 \\
b4 & 100 & 97 & 96 & 16 & 66 & 21 & 83 \\
b5 & 100 & 100 & 51 & 88 & 100 & 61 & 25 \\
b6 & 80 & 80 & 90 & 90 & 80 & 50 & 90 \\
b7 & 78 & 81 & 72 & 84 & 59 & 79 & 92 \\
b8 & 80 & 90 & 70 & 90 & 70 & 70 & 70 \\
b9 & 90 & 90 & 90 & 90 & 80 & 90 & 90 \\
b10 & 90 & 80 & - & - & - & - & - \\
b11 & 80 & 90 & - & - & - & - & - \\
b12 & 90 & 70 & 80 & 90 & 80 & 90 & 60 \\
b13 & 70 & 90 & 90 & 90 & 90 & 30 & - \\
b14 & 60 & 60 & 90 & 80 & 50 & 30 & 50 \\
b15 & 50 & 50 & 90 & 70 & 30 & 30 & 30 \\
b16 & 70 & 60 & 90 & 90 & 90 & 50 & 80 \\
b17 & 70 & 90 & 50 & 80 & 90 & - & - \\
b18 & 50 & 50 & 90 & 90 & 90 & 80 & 30 \\
b19 & 90 & 90 & 70 & 60 & 70 & 30 & 50 \\
\hline
\end{tabular}




\begin{tabular}{|c|ccccccc}
\hline b20 & - & - & - & 90 & - & 90 & 90 \\
b21 & 80 & 58 & 62 & 46 & 88 & - & - \\
b22 & 83 & 98 & - & - & - & - & - \\
b23 & 84 & 75 & - & - & - & - & - \\
b24 & 90 & 74 & - & - & - & - & - \\
b25 & 90 & 90 & 70 & 80 & 70 & 50 & 50 \\
b26 & 90 & 80 & - & - & - & - & - \\
b27 & 90 & 80 & - & - & - & - & - \\
b28 & 90 & 90 & 70 & 60 & 70 & 10 & 30 \\
b29 & 90 & 90 & 90 & 80 & 80 & 50 & 60 \\
b30 & 13 & 4 & - & - & - & - & - \\
b31 & 73 & 94 & - & - & - & - & - \\
b32 & 34 & 78 & - & - & - & - & - \\
b33 & 22 & 31 & - & - & - & - & - \\
b34 & 21 & 100 & 3 & 7 & 7 & - & - \\
b35 & 77 & 100 & 44 & 97 & 19 & - & - \\
b36 & 99 & 100 & 43 & 89 & 12 & - & - \\
b37 & 86 & 90 & 89 & 100 & 92 & - & - \\
b38 & 75 & 79 & - & - & - & - & - \\
\hline
\end{tabular}

2.3.3 Determination of weight

Determining the weight of the evaluation index is the difficulty in the construction of the evaluation system. There are many methods to determine the weight. Each method has its advantages and disadvantages $(\mathrm{Ni}$, 2002). Subjective weighting methods are highly subjective, the data can not be true and reliable. Objective weighting method uses rigorous mathematical algorithms and require accurate data. 38 indicators are selected in the study, which are tedious to deal with. Therefore, in order to scientifically determine the weight of the index and accurately summarize the situation of the island, the research adopts factor analysis

212 to determine the weight.

In this study, spss software is used to reduce the dimension of the data by factor analysis. There are 38 indicators and 7 samples in total. First, the indicators are qualitatively divided into five element layers, including social element layer, tourism element layer, ecological element layer, resource element layer and economic element layer. Using the average grouping method to weight the elements, the weight of a single feature layer is $20 \%$. Then, perform factor dimensionality reduction analysis on the selected indicators of each element layer. In the course of the experiment, the over-correlated variables and invalid data were removed to meet the KMO and Bartlett test conditions (KMO > $0.5 \& \mathrm{Sig}<0.05)$.

Considering the characteristics of the island itself, the development and construction of the island's society, tourism, ecology, resources and economy will restrict and influence each other and cannot be regarded as unrelated factors. Factor analysis requires that the number of indicators is less than the number of samples. However, this study contains 38 indicators and 7 samples. Therefore, this study considers both the principles and data, divides the indicators into different modules, and performs factor analysis on each module.

In the experiment, a total of 38 indexes were investigated, 10 indexes with strong correlation were removed, and 28 indexes were used for factor analysis and dimensionality reduction. The experiment qualitatively divides the indicators into 6 modules, and then carries out factor analysis on the 6 modules respectively. 229 After continuous index adjustment, factor analysis divides 38 indicators into 9 principal factors. 


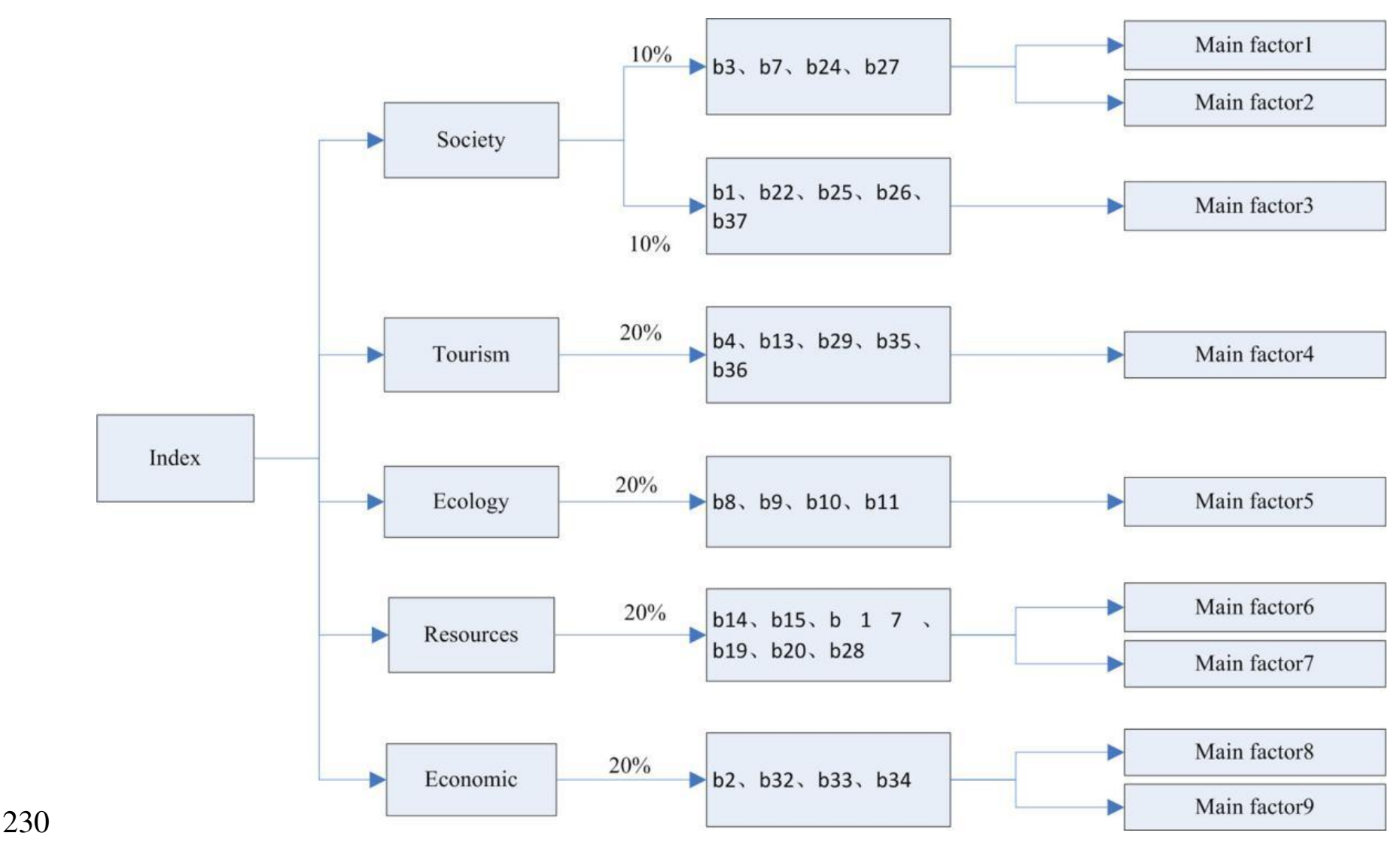

231 Fig. 4 spss experiment process diagram

232 Factor analysis can reduce the dimension of the index and transform the general index into several groups

233 of unrelated comprehensive factors through linear combination. The main factor is the linear combination

234 of the index, and the score of the main factor can be obtained according to the score coefficient matrix.

235 The main factor weight formula of factor analysis is as follows:

$236 \omega_{i}=\frac{e_{i}}{\sum e_{i}}$

237 In the formula, $\omega$ i is the weight of the index, ei is the contribution rate of the main factor.

238 The main factor score formula is as follows:

$239 \quad \boldsymbol{Y}_{\boldsymbol{i}}=\sum \boldsymbol{A}_{\boldsymbol{i j}} \times \boldsymbol{y}_{j}$

240 In the formula: Yi is the score of the main factor, Aij is the score coefficient matrix, $y$ is the standardized

241 value of the index.

242 The weights and scores of the main factors are calculated by using formulas (4) and (5), and the results are

243 shown as follows:

244 Table 5 Factor weights and scores

$\begin{array}{lllll}\text { Essential } & \text { Principal } & \text { Variance contribution } & \text { Main factor } & \text { Factor score calculation }\end{array}$




\begin{tabular}{|c|c|c|c|c|}
\hline factor & factor & $\operatorname{rate}(\mathrm{e}) / \%$ & weight $(\omega) / \%$ & expression(Y) \\
\hline \multirow{3}{*}{ Society } & $\begin{array}{l}\text { Principal } \\
\text { factor } 1\end{array}$ & 61.136 & 7.007 & $\mathrm{Y}_{1}=0.39 \mathrm{y}_{27}+0.39 \mathrm{y}_{24}+0.326 \mathrm{y}_{3}-0.29 \mathrm{y}_{7}$ \\
\hline & $\begin{array}{l}\text { Principal } \\
\text { factor } 2\end{array}$ & 26.118 & 2.993 & $\begin{array}{c}\mathrm{Y}_{2}=0.091 \mathrm{y}_{27}+0.087 \mathrm{y}_{24-} \\
0.248 \mathrm{y}_{3}+0.94 \mathrm{y}_{7}\end{array}$ \\
\hline & $\begin{array}{l}\text { Principal } \\
\text { factor } 3\end{array}$ & 79.943 & 10.000 & $\begin{array}{c}\mathrm{Y}_{3}=0.245 \mathrm{y}_{1}+0.234 \mathrm{y}_{22}+0.234 \mathrm{y}_{25}+0.16 \\
\mathrm{y}_{37}+0.234 \mathrm{y}_{26}\end{array}$ \\
\hline Tourism & $\begin{array}{l}\text { Principal } \\
\text { factor } 4\end{array}$ & 78.429 & 20.000 & $\begin{array}{c}\mathrm{Y}_{4}=0.233 \mathrm{y}_{36}+0.237 \mathrm{y}_{35}+0.227 \mathrm{y}_{29}+0.22 \\
4 \mathrm{y}_{13}+0.208 \mathrm{y}_{4}\end{array}$ \\
\hline Ecology & $\begin{array}{l}\text { Principal } \\
\text { factor } 5\end{array}$ & 64.471 & 20.000 & $\begin{array}{c}Y_{5}=0.298 y_{8}+0.182 y_{9}+0.362 y_{10}+0.367 \\
y_{11}\end{array}$ \\
\hline \multirow{2}{*}{ Resources } & $\begin{array}{l}\text { Principal } \\
\text { factor } 6\end{array}$ & 56.780 & 12.494 & $\begin{array}{c}\mathrm{Y}_{6}=-0.099 \mathrm{y}_{14}-0.308 \mathrm{y}_{20^{-}} \\
0.149 \mathrm{y}_{15}+0.263 \mathrm{y}_{17}+0.302 \mathrm{y}_{19}+0.281 \mathrm{y}_{28}\end{array}$ \\
\hline & $\begin{array}{l}\text { Principal } \\
\text { factor } 7\end{array}$ & 34.110 & 7.506 & $\begin{array}{c}\mathrm{Y}_{7}=0.52 \mathrm{y}_{14}+0.134 \mathrm{y}_{20}+0.561 \mathrm{y}_{15^{-}} \\
0.035 \mathrm{y}_{17^{-}}-0.072 \mathrm{y}_{19^{-}}-0.011 \mathrm{y}_{28}\end{array}$ \\
\hline \multirow{2}{*}{ Economy } & $\begin{array}{l}\text { Principal } \\
\text { factor } 8\end{array}$ & 71.604 & 14.383 & $\begin{array}{c}\mathrm{Y}_{8}=0.348 \mathrm{y}_{32}+0.313 \mathrm{y}_{33}+0.366 \mathrm{y}_{34}+0.07 \\
\mathrm{y}_{2}\end{array}$ \\
\hline & $\begin{array}{l}\text { Principal } \\
\text { factor } 9\end{array}$ & 27.963 & 5.617 & $\begin{array}{c}\mathrm{Y}_{9}=0.006 \mathrm{y}_{32-} \\
0.191 \mathrm{y}_{33}+0.23 \mathrm{y}_{34}+0.91 \mathrm{y}_{2}\end{array}$ \\
\hline
\end{tabular}

$245 \quad 2.3 .4$ Comprehensive processing of index factors

246 The index weights are integrated to analyze the overall environmental conditions of the island, and the

247 weighting formula is shown as follows:

$248 \boldsymbol{S}=\sum \boldsymbol{\omega}_{\boldsymbol{i}} \times \boldsymbol{Y}_{\boldsymbol{i}}$

249 In the formula, $\omega \mathrm{i}$ is the weight and $\mathrm{Yi}$ is the standardized value of the $\mathrm{i}$ th main factor.

\section{RESULTS AND DISCUSSION}

\section{$251 \quad 3.1 \quad$ Factor analysis condition test}

252 Factor analysis requires KMO and Bartlett test conditions $(\mathrm{KMO}>0.5 \& \mathrm{Sig}<0.05)$. The research carried out $253 \mathrm{KMO}$ and Bartlett tests on 6 modules respectively. 

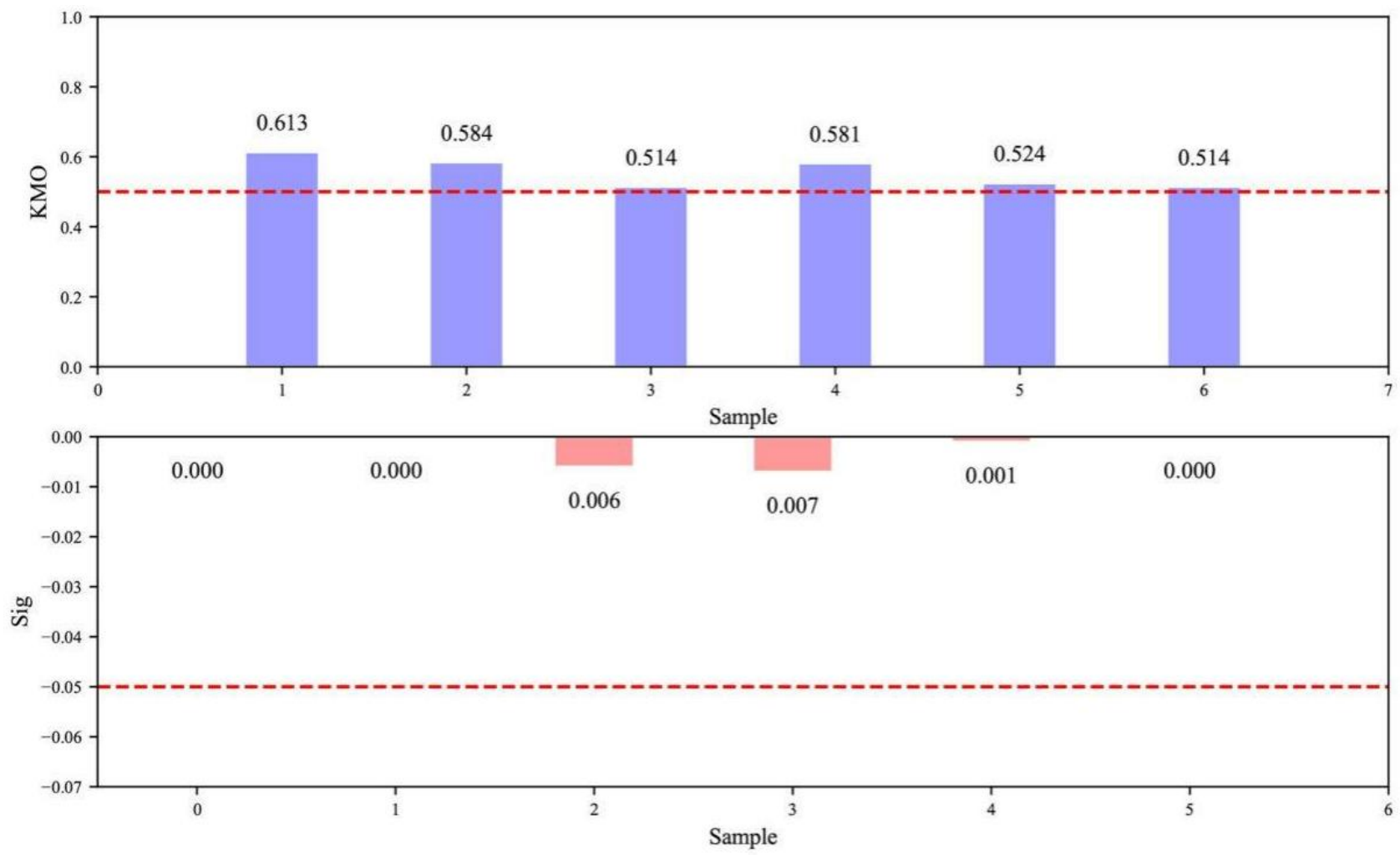

255 Fig. $5 \mathrm{KMO}$ and Bartlett spherical test results

256 As can be seen from Figure 5, the KMO test results of the 6 modules are all greater than 0.5 , and the 257 Bartlett sphere test results are all less than 0.05 . The results meet the conditions of factor analysis variable 258 test, and prove that the adjusted index can be used for dimensional reduction experiment through factor 259 analysis.

\section{$260 \quad 3.2 \quad$ Island factor score}

261 The total scores of social factors, tourism factors, ecological factors, resource factors and economic factors

262 are calculated using formula (6), and the score results are shown as follows:

\section{Table 6 Factor scores}

\begin{tabular}{cccccc}
\hline Island & Social factor score & $\begin{array}{c}\text { Tourism factor } \\
\text { score }\end{array}$ & $\begin{array}{c}\text { Ecological factor } \\
\text { score }\end{array}$ & $\begin{array}{c}\text { Resource factor } \\
\text { score }\end{array}$ & $\begin{array}{c}\text { Economic } \\
\text { factor score }\end{array}$ \\
\hline D1 & 17.376 & 19.645 & 20.432 & 10.886 & 7.515 \\
D2 & 15.876 & 21.553 & 21.038 & 11.490 & 17.668 \\
D3 & 4.430 & 16.201 & 7.448 & 10.688 & 6.315 \\
D4 & 5.277 & 17.075 & 8.640 & 7.635 & 6.577 \\
D5 & 4.156 & 11.869 & 7.084 & 9.421 & 6.577 \\
D6 & 2.274 & 4.488 & 7.448 & 0.259 & 6.118 \\
D7 & 2.684 & 6.177 & 7.448 & 2.125 & 4.956 \\
\hline
\end{tabular}




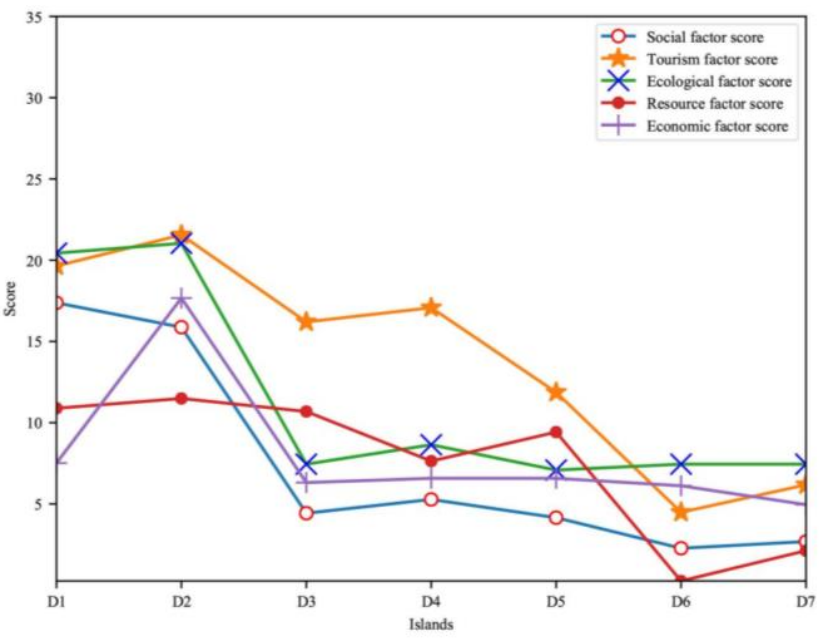

265 Fig. 6 Value of factor score

266 Figure 6 shows that the individual factor scores of social islands, tourist islands and ecological islands all 267 have a downward trend. Compared with other factors, the downward trend of resource factor is more 268 moderate. The scores of social, tourism, ecological, resource and economic factors of social islands are 269 higher than those of other types of islands. The scores of social, tourism, ecological, resource and economic factors of ecological islands are lower than those of other types of islands. The scores of tourism factors of tourist islands are significantly higher than those of other factors, and the scores of ecological factors of ecological islands are significantly higher than the scores of other factors.

Analyzing the results of the island factor score in Figure 6, the score of a single factor shows a downward trend, indicating that there is a certain correlation between the factors. The figure shows that the various factors are positively correlated. The main reason is that in the process of island development, society, tourism, ecology, resources, and economy will restrict and influence each other. Compared with other factors, the change trend of resource factor is more gradual. This is mainly because resource factors are less affected by human activities than social factors, ecological factors, tourism factors, and economic factors. Social, tourism, economic, and ecological factors are formed by human participation in the construction of islands, which are more affected by human activities and have more drastic changes. It shows that the value of an island is not only affected by the characteristics of the island itself, but also restricted by human development and construction activities.

The scores of the five factors of social islands are higher than those of tourist islands and ecological islands, indicating that social islands have the highest level of development and utilization. The social, ecological, resource, economic, and tourism factors are all at a relatively high level, which implies that the development of social islands is balanced. Ecological islands are mostly uninhabited islands. Although they are rich in ecological resources, they are ecologically fragile and the islands are almost in an undeveloped state. Tourist islands are rich in natural landscapes, mainly for the development of tourism. The scores on ecological factors of ecological islands are significantly higher than the values of other factors. Shanhu Island has valuable resources such as coral reefs, and Shedao Island has unique snake resources. Therefore, both islands have high ecological protection value. The evaluation result is consistent with the actual situation of the islands.

\section{$293 \quad 3.3 \quad$ Island total value score}

294 Formula (6) is used to obtain the total score of the island.

295 Table 7 Total value score of island 


\begin{tabular}{cccccccc}
\hline Island & D1 & D2 & D3 & D4 & D5 & D6 & D7 \\
\hline Total score & 75.854 & 87.625 & 45.082 & 45.203 & 39.108 & 20.587 & 23.390 \\
\hline
\end{tabular}

Table 7 shows that Zhoushan Islands have the highest score of 87.625, and Snake Island has the lowest score of 20.587. Social islands such as Chongming Island and Zhoushan Islands have the highest scores, exceeding 70; tourist islands have a medium score, around 40; ecological islands have the lowest score, around 20 .

The evaluation results of seven typical islands show that the comprehensive value of social islands is higher than that of tourist islands, while the comprehensive value of ecological islands is the lowest. The total value of Chongming Island and Zhoushan Islands is the highest compared to other islands. The results indicate that the development of Chongming Island and Zhoushan Islands is in good condition, the facilities on the islands are well constructed, and the islands have the strongest development level. On the one hand, this phenomenon is due to the large area of Chongming Island and Zhoushan Islands, the large population base, and the high level of social development that drives the level of island development and utilization. On the other hand, their social development and the island's natural level are relatively balanced. Weizhou Island, Miaodao Islands and Nanji Island are second in value. This is mainly due to the relatively small area of the island, the small inhabitant population and the uneven development of the island. The islands have a focus on development according to their own characteristics. There are some residents living on Weizhou Island, Miaodao Islands, and Nanji Island. The islands have rich and unique natural landscapes. Good natural scenery and ecology have attracted a large number of tourists. The residents of the islands mainly make a living from fishing and tourism. Therefore, these three islands are defined as tourist islands. Due to their geographical location and geographical area, these islands are not suitable for a large number of residents. The degree of islands development and construction is lower than that of Chongming Island and Zhoushan Islands. The islands mainly relies on the development of tourism, and their value will be relatively low. Shedao Island and Shanhu Island have the smallest value and the weakest level of development. They are in the undeveloped or weakly developed stage. The two islands are uninhabited islands and are almost undeveloped. The islands are very small and lack fresh water resources, which is not conducive to the lives of residents. Shedao Island is the only island in the world where survives a single species of black-browed vipers. The toxins of vipers have scientific research value. China has established nature reserves to protect snake resources and the survival and reproduction of vipers. Shanhu Island is an island composed of coral reefs. The island is rich in corals and rich in guano resources. At the same time, it is one of the islands with abundant phosphate rock. Shedao Island and Shanhu Island are islands that cherish ecological resources. Although the degree of development and construction of the islands is very weak, the ecological value of resources cannot be ignored.

The results of the overall evaluation of different types of islands show that the value of islands with balanced development is higher than that of islands with unbalanced development or undeveloped islands. However, the contradiction between development and the environment is more prominent in islands with fragile ecosystems. How to achieve balanced development and sustainable development is currently facing huge challenges. The main problem of island development is the lack of correct technical guidance. The formulation of an island development plan first requires a scientific assessment of the island to fully understand the island. Compared with the previous environmental assessment of a single island by experts and scholars in related fields, this study compares and analyzes the environmental evaluation of different types of islands. The evaluation results are consistent with the actual development level on the island, which illustrates the feasibility and accuracy of the model. And the experimental results verify that the model can be applied to the unified evaluation of different types of islands. Factor analysis methods are rarely used in the evaluation of sustainable development of islands in previous studies. The study verifies the feasibility of factor analysis and dimension reduction method in the evaluation of islands through examples, and provides a solution to the problem of index selection in the evaluation process. At the same time, through qualitative analysis of indicators of different types of islands, different standardized equations are proposed. For the indicators of different types of islands, set appropriate weights to make the data standardization more fair. The limitation of the model is that the Delphi method has many limitations. The Delphi method is highly subjective, and the opinions of experts can easily influence each other, resulting in inaccurate results. In addition, the model has only been verified for its applicability in the field of islands.

346 As an independent geographic unit, islands are less affected by land. Therefore, the indicator setting can 
ignore external influences and mainly consider the internal factors of the islands. Using different types of islands as samples for unified evaluation will have smaller errors. However, in theory, the model can also be used in coastal or inland areas as long as the indicators are set reasonably. The specific feasibility needs

350 further verification.

\section{Declarations}

\section{$352 \quad 4.1 \quad$ Ethics approval and consent to participate}

353 Not applicable

\section{$354 \quad 4.2 \quad$ Consent for publication}

355 All authors are responsible for the article and agree to publish.

\section{$356 \quad 4.3 \quad$ Availability of data and materials}

357 In this study, the environmental data of the seven islands mainly come from two kinds of websites(Table 2).

358 One is the official website of local government, including the municipal government official website and

359 the district government official website, and the other is the local tourism website. Among them, most of

360 the indicator data comes from the statistical yearbook on the government website. The datasets of both

361 websites are open to public readers.

\section{$362 \quad 4.4 \quad$ Competing interests}

363 The authors declare that they have no competing interests.

\section{$364 \quad 4.5 \quad$ Funding}

365 The work is supported by the Research Foundation from Ministry of Education of China(No. 18JZD059),

366 Tianjin Philosophy and Social Science Planning Project of China(No. TJKS20XSX-015).

\section{$367 \quad 4.6 \quad$ Authors' contributions}

368 Shaoyang Chen: Conceptualization, Data curation, Formal analysis, Funding acquisition, Writing-original 369 draft. Na Liu: Data curation, Formal analysis, Funding acquisition, Writing-original draft. Li Xiao:

370 Supervision, Writing-review \& editing. Yanwei Gong: Supervision, Writing-review \& editing. Yun Xiao:

371 Writing-review \& editing.

\section{$372 \quad 4.7 \quad$ Acknowledgements}

373 Anonymous reviewers are thanked for their reviews of the original manuscript. Professors from the

374 Department of Marine Science and Technology of Tianjin University and experts from the National Marine

375 Data and Information Service are thanked for scoring the qualitative indicators of this evaluation. The work

376 is supported by the Research Foundation from Ministry of Education of China(No. 18JZD059), Tianjin

377 Philosophy and Social Science Planning Project of China(No. TJKS20XSX-015).

\section{CONCLUSION}

379 The value of balanced islands is higher than that of unbalanced or undeveloped islands, 380 indicating that the development of islands needs to take the path of sustainable

381 development. The rational development and utilization of islands should undergo overall

382 planning after ecological assessment. The research puts forward factor analysis

383 evaluation model, and conducts example evaluations for seven different types of islands.

384 The results show that the model can use multiple types of islands as samples for unified 
evaluation. This not only reduces the amount of calculation for evaluating individual islands, but also facilitates the analysis of the development of different types of islands. Furthermore, this is conducive to the country's macro-control of the development of different types of islands and the classified and hierarchical management of islands. Meantime, the model can effectively deal with the complexity of calculations and the relevance of indicators caused by numerous indicators, making the evaluation results more accurate. Last but not least, the research has improved the SAVEE standardization equation to standardize data for different types of islands. The model needs more indicators as data support. However, data collection is a difficult point, requiring a large amount of information to be collected and integrated. The current research has only verified the application of the model in the field of islands. In theory, the model has universal applicability and can be used for evaluation in other fields. Further attempts can be made to apply the model to coastal zones or coastal areas. So far, the model has been successfully applied to the field of islands in experiments, which can provide data and technical support for the scientific development of islands.

\section{REFERENCES}

401 Baldacchino G (2006) Managing the hinterland beyond: two ideal-type strategies of economic development 402 for small island territories. Asia Pacific Viewpoint. 47(1):45-60. doi: 10.1111/j.1467-8373.2006.00295.x

403 Brauko KM, Cabral A, Costa NV, Hayden J, Dias CEP, Leite ES, Westphal RD, Mueller CM, Hall404 Spencer JM, Rodrigues RR, Rorig LR, Pagliosa PR, Fonseca AL, Alarcon OE, Hortat PA (2020) Marine 405 Heatwaves, Sewage and Eutrophication Combine to Trigger Deoxygenation and Biodiversity Loss: A SW

406 Atlantic Case Study. FRONTIERS IN MARINE SCIENCE 7:590258. doi: 10.3389/fmars.2020.590258

407 Chen QH, Dong HN (2019) Sustainable development indicator systems for island cities: the case of 408 zhoushan maritime garden city. Island Studies Journal 14(2):137-156. doi: 10.24043/isj.103

409 Chen SY (2011) Evaluation of the rights and strategic value of the Nansha Islands based on the savee 410 method. Chinese Fisheries Economics 29(03):63-67.

411 del Rio-RamaMD, Maldonado-Erazo CP, Alvarez-Garcia J, Duran-Sanchez A (2020) Cultural and Natural 412 Resources in Tourism Island: Bibliometric Mapping. Sustainability 12(2):724. doi: 10.3390/su12020724

413 Douglas CH (2006) Small island states and territories: sustainable development issues and strategies 414 challenges for changing islands in a changing world. Sustainable Development 14(2):75-80. doi:

$41510.1002 / \mathrm{sd} .297$

416 Fang K, Zhang Q, Yu H, Wang Y, Dong L, Shi L (2018) Sustainability of the use of natural capital in a city: 417 Measuring the size and depth of urban ecological and water footprints. Science of the Total Environment 418 631-632:476-484. doi: 10.1016/j.scitotenv.2018.02.299.

419 Gao S, Sun H, Zhao L, Wang R, Xu M, Cao G (2019) Dynamic assessment of island ecological 420 environment sustainability under urbanization based on rough set, synthetic index and catastrophe progression analysis theories. Ocean and coastal management 178:104790. doi: 10.1016/j.ocecoaman.2019.04.017

423 Gilman E, Owens M, Kraft T (2014) Ecological risk assessment of the marshall islands longline tuna 424 fishery. Marine Policy 44:239-255. doi: 10.1016/j.marpol.2013.08.029 
Hafezi M, Giffin AL, Alipour M, Sahin O, Stewart RA (2020) Mapping long-term coral reef ecosystems regime shifts: a small island developing state case study. Science of The Total Environment 716:137024. doi: 10.1016/j.scitotenv.2020.137024

He CY, Wang JQ, Yan XJ, Meng KH (2020) Assessing development intensity and ecological risk of islands on the eastern coast of China: Promotion of refined classification management. Ocean and Coastal Management 198:105318. doi: 10.1016/j.ocecoaman.2020.105318

He J, Wang X (2020) The United Nations in the Process of Global Ocean Governance: Role, Dilemma and Way Out. International Studies (04):174-192.

Hwang J, Ko K (2018) The Effect of Non-resident Jejurian's Regional Attachment on the Attitude toward Tourism Development in Jeju Island: Focused on the Mediating Effect of Regional Identity. Tourism Research 43(03):229-248. doi: 10.32780/ktidoi.2018.43.3.229

Karampela S, Papazoglou C, Kizos T, Spilanis I (2017) Sustainable local development on aegean islands: a meta-analysis of the literature. Island Studies Journal 12(1):71-94. doi: 10.24043/isj.6

Karcher DB, Fache E, Breckwoldt A, Govan H, Sabinot C (2020) Trends in south pacific fisheries management. Marine Policy 118:104021. doi: 10.1016/j.marpol.2020.104021

Ke LN, Wang QM, Gai M, Zhou HC (2014) Assessing seawater quality with a variable fuzzy recognition model. Chinese Journal of Oceanology and Limnology 32(003):645-655. doi: 10.1007/s00343-014-3117-3

Ke LN, Wang QM, Li YH, Cao YQ (2013) An evaluation model of island sustainable development based on variable fuzzy set theory: A case study of Changhai County, Liaoning Province. Journal of Natural Resources 28(05):832-843.

Kim SP (2020) Mainland development policy in an autonomous subnational island jurisdiction: spatial development and economic dependence in jeju, south korea. Island Studies Journal 15(1):169-184. doi: $10.24043 /$ isj.76

Li JK, Wang GC (2004) Establishment and discussion of appraisement indicators system ofIslands stainable development. Marine Environmental Science (01):54-57.

Li XJ, Chen LL, Zhou ZQ, Li BQ, Liu X, Yang LF, Liu B, Song B (2020) Spatio-temporal variation of subtidal macrobenthic fauna and the ecological assessment of Longkou Artificial Island construction in Bohai Sea,China. Journal of Oceanology and Limnology (06):1 811-1 824. doi: 10.1007/s00343-019-90985

Liao MS, Liu Y (2019) Development and Theoretical Evolution of National Maritime Strategies since the Founding of PRC. Pacific Journal 27(012):88-97. doi: 10.14015/j.cnki.1004-8049.2019.12.008

Liu C, Cui WL, Zhu ZT, Ye F, Yu XJ (2018) Study on the technical methods of the delineation of island ecological red lines. Acta Ecologica Sinica 38(23):8564-8573. doi: 10.5846/stxb201712132243

Liu SG, Shang YS, Yin P (2020) An empirical study on the coupling and coordination of tourism efficiency and economic growth in island counties of China. Chinese Fisheries Economics 38(03):75-83.

Liu X, Wang S, Jiang Y, Sun Y, Li J, Zhang G (2017) Polychlorinated biphenyls and polybrominated diphenylethers in soils from planted forests and adjacent natural forests on a tropical island. Environmental Pollution 227:57-63. doi: 10.1016/j.envpol.2017.04.042

Long XY, Yu HJ, Sun MX, Wang XC, Klemes JJ, Xie W, Wang CD, Li WQ, Wang YT (2020)

Sustainability evaluation based on the Three-dimensional Ecological Footprint and 

Management 265:110509. doi: 10.1016/j.jenvman.2020.110509

467 Mauthoor S (2017) Uncovering industrial symbiosis potentials in a small island developing state: the case

468 study of mauritius. Journal of Cleaner Production 147:506-513. doi: 10.1016/j.jclepro.2017.01.138

469 Moreno PS (2005) Ecotourism along the meso-american caribbean reef: the impacts of foreign investment. Human Ecology 33(2):217-244. doi: 10.1007/s10745-005-2433-9

471 Nesticò A, Maselli G (2020) Sustainability indicators for the economic evaluation of tourism investments 472 on islands. Journal of Cleaner Production 248:119217. doi: 10.1016/j.jclepro.2019.119217

473 Ni SK (2002) Comparison of 7 methods for determining the weights of evaluation indicators. South China 474 Journal of Preventive Medicine 28(006):54-55.

475 Pan C Y, Li L, Zhou ZJ, Jin SP, Wang KN, Feng T (2018) Design Essentials for Small Desalination 476 Devices. Water purification technology 37(z1):149-151. doi: 10.15890/j.cnki.Jsjs.2018.s1.039

477 Petridis P, Fischer-Kowalski M, Singh SJ, Noll D (2017) The role of science in sustainability transitions: 478 citizen science, transformative research, and experiences from Samothraki island, Greece. Island Studies 479 Journal 12(1):115-134. doi: 10.24043/isj.8

480 Rigg GB, Richardson CT (1934) The development of sphagnum bogs in the san juan islands. American 481 Journal of Botany 21(10):610-622. doi: 10.2307/2436280

482 Sealey KS, Lennon E, Patus J (2019) A Hurricane Rapid Ecological Assessment (H-REA) Method for 483 Small Island Developing States in 2017 and Beyond. Estuaries and Coasts 43(5):1284-1297. doi:

484 10.1007/s12237-019-00646-7

485 Shen WZ (1995) The historical evolution of my country's island development. Ocean Development and 486 Management 6(02):56-61.

487 Shi XF, Sun H, Long C, He WH (2015) Investigation on the status quo and countermeasures of inhabited 488 islands in Guangdong Province. Ocean Development and Management 32(01):41-48.

489 Tilley A, Wilkinson SP, Kolding J, Lopez-Angarita J, Pereira M, Mills DJ (2019) Nearshore Fish 490 Aggregating Devices Show Positive Outcomes for Sustainable Fisheries Development in Timor-Leste. 491 FRONTIERS IN MARINE SCIENCE 6:487. doi: 10.3389/fmars.2019.00487

492 Tokusige E (1939) Shore-line development along the coast of ogi, sado island. Geographical Review of 493 Japan 15(11):795-806. doi: 10.4157/grj.15.11_795

494 Towns DR, Ballantine WJ (1993) Conservation and restoration of New Zealand Island ecosystems. Trends 495 in Ecology \& Evolution 8(12):452-457. doi: 10.1016/0169-5347(93)90009-E

496 Wang HZ, Luan WX, Li PJ, Wang YW (2006) The evolution, dynamics and regulation of maritime traffic in the Changshan Islands. Pacific Journal (04):67-75.

$498 \mathrm{Xu} \mathrm{CB}, \mathrm{Li} \mathrm{X}, \mathrm{Wu}$ XH (2020) Evaluation of island tourism sustainable development in the context of smart 499 tourism. Journal of Coastal Research 103(sp1):1098. doi: 10.2112/SI103-229.1

500 Yang SY, Lin GH, Meng K, Xu HF (2019) Review of the Construction Methods for the Performance 501 Evaluation Index System for Clinical Pharmacists. China Pharmacist 22(10):1910-1914. 
505 Zhang CP, Zheng ZY, Yao SH, Jia HL, Wang L (2020) Ecological risk of heavy metals in sediment around 506 techeng island special marine reserves in zhanjiang bay. Journal of Ocean University of China 19(3):561-

507 568. doi: 10.1007/s11802-020-4042-z

508 Zhang H, Xiao Y (2020) Planning island sustainable development policy based on the theory of ecosystem

509 services: A case study of Zhoushan Archipelago, East China. Island Studies Journal (15):237-252. doi:

$510 \quad 10.24043 /$ isj. 105

511 Zhang H, Liu ZY, Constantinescu E, Jacob R (2020) Stability analysis of interface conditions for ocean-

512 atmosphere coupling. Journal of entific Computing 84(3):2484-2512. doi: 10.1007/s10915-020-01293-y

513 Zhao J, Shen G, Yan LJ, Huang L, Jin AM, Huo SG (2016) Assessment and spatiotemporal analysis of the 514 ecosystem services value of island:a case study of Jintang Island. Acta Ecologica Sinica 36(23):7768-7777.

515 doi: $10.5846 / \mathrm{stxb} 201511182328$

516 Zhao SD, Zheng Y (2017) A Complex Model to Assess Economic Growth of China's Island Counties:A

517 Case Study of Changdao County. Science and Management 37(001):49-53. doi: 10.3969/j.issn.1003-

$518 \quad 8256.2017 .01 .008$

519 Zheng J, Pan CH, Yao WW, Mu JB, Zhao X (2020) Analysis on the current situation and key problems of 520 artificial island development in china. IOP Conference Series: Earth and Environmental

521 Science 510(6):062012. doi: 10.1088/1755-1315/510/6/062012

522 Zheng WH, Cai F, Chen SL, Zhu J, Qi HS, Cao HM, Zhao SH (2019) Beach management strategy for 523 small islands: case studies of china. Ocean and Coastal Management 184:104908. doi:

524 10.1016/j.ocecoaman.2019.104908

525 Zhu WW, Wang HJ (2017) Comprehensive Evaluation Method and Application of Regional Sustainable

526 Development Capacity: Perspective of Slack Based Network DEA. Environmental Science and Technology 527 40(06):192-200. doi: 10.3969/j.issn.1003-6504.2017.06.032 